\title{
Mapping the environmental field with the help of library classification systems
}

\section{Camille Biros}

\section{(2) OpenEdition}

\section{Journals}

Electronic version

URL: http://journals.openedition.org/asp/3834

DOI: $10.4000 /$ asp.3834

ISSN: 2108-6354

\section{Publisher}

Groupe d'étude et de recherche en anglais de spécialité

\section{Printed version}

Date of publication: 1 November 2013

Number of pages: $51-73$

ISSN: 1246-8185

\section{Electronic reference}

Camille Biros, « Mapping the environmental field with the help of library classification systems », ASp [Online], 64 | 2013, Online since 01 November 2014, connection on 02 November 2020. URL : http:// journals.openedition.org/asp/3834; DOI : https://doi.org/10.4000/asp.3834

This text was automatically generated on 2 November 2020

Tous droits réservés 


\title{
Mapping the environmental field with the help of library classification systems
}

\author{
Camille Biros
}

1 The environmental domain is not a territory that has been traditionally explored in English for specific purposes as practiced in France (Laffont \& Trouillon 2013: 145). However, many social scientists have found an interest in examining environmental discourse, adopting different disciplinary approaches: terminology (Dury 2006, 2007), communication studies (Libaert 2004, 2008; Jalencques-Vigouroux 2006), intertextuality (Fløttum 2010), rhetoric (Myerson \& Rydin 1996), critical discourse analysis and ecolinguistics (Fill \& Mühlhäusler 2001; Mühlhäusler 2005). If these studies provide clear illustrations of the fact that the environmental domain could be a field of interest, little work has been done on the definition of this specialised domain which can be seen as still to be explored. Like all explorations, this one proves challenging. One of the main challenges the researcher may be confronted with when considering this field as a specialised domain is its multidisciplinarity. The problems of environmentalism ${ }^{1}$ and the protection of our environment require those who deal with them to adopt a multidisciplinary approach. Specialists from different disciplinary fields need to build bridges between their different perspectives, otherwise the means to solve environmental problems will remain beyond reach.

2 To foster dialogue, it is necessary to work on the language used by specialists. The gap between specialists from different disciplines widens when they do not use the same terms to speak about the same phenomenon, or when they use words without agreeing on their definition. Specialists need to have shared references providing them with complete definitions of the terms which they employ. Their possible polysemy should be pointed out in documents related to environmental issues. Environmental dictionaries could and should play this essential role. Although quite recent, these publications are developing fast and studying them provides much useful information on the environmental field. Firstly, environmental dictionaries help to date the field as 
the publication of a specialised dictionary can be seen as an essential step for the emergence of a new specialised field: "En termes imagés, la dictionnarisation coupe le cordon ombilical entre la langue générale et la langue spécialisée et constitue, mieux que toute autre déclaration, un symptôme de [l'emergence de celle-ci]" (Van Der Yeught 2009: 33). The study of environmental dictionaries can also help to draw up a list of the terms most relevant to this field. Finally, it provides valuable information on the ways in which environmental terms relate to traditional disciplinary fields, and this third point is the one which is explored in this article.

3 The study presented here was triggered from a very pragmatic consideration. An essential step for anyone who is interested in environmental terminology will be to gather as much written material as possible on the issue, in particular by investigating available environmental dictionaries. If this first step is performed in a well-equipped library, it may soon be realised that the works of interest are scattered on its shelves over several sections. In most libraries there is no environmental section which groups them all, let alone an environmental terminology section. Instead, many different shelves, not always in the same reading room, have environmental dictionaries. The logic behind this classification is often very difficult to work out. Faced with this reality, the author was drawn to reflect upon the criteria used to sort the different works about specialised terms linked to environmental protection, working from the selection of environmental dictionaries found in the catalogue of the British National Library (BNL). An introduction to classification systems will be presented as a starting point, followed by a description of the ways the different dictionaries composing the corpus fall into the different sections of the system adopted by the BNL. This provides an overview of the disciplinary orientations one may find in the environmental field. So as to better understand the reason why different books from the catalogue are dispatched into these different sections, a comparison of these works is required. A first criterion for comparison lies in the titles themselves, which may give precious information about the disciplinary orientations of the different dictionaries. Finally, an analysis of the content of the dictionaries is provided, so as to investigate distinctions in the way terms are defined.

\section{The classification of environmental dictionaries at the British National Library}

\subsection{Classification systems in libraries}

Looking at indexing systems to learn more about specialised domains is not a new idea. Indexing systems have been of great use for the development of terminology, which is an essential branch of English for specific purposes. Eugen Wüster, often considered as the father of terminology, used the Universal Decimal Classification system to delineate the domains and sub-domains on which the definition of terms depended in his systematic dictionary entitled The Machine Tool (1968). Domains form an essential part of his theory. Library science requires the identification of semantic relations between key words, often represented with an arborescence. The physical classification of books on the shelves of a library depends on these key words. Terminology is also based on determining the semantic relations between terms. Both sciences use descriptors, that is to say well-defined unequivocal terms to manage this classification. Both sciences are 
thus based on a reflection on domains and the key words which enable to describe them in relation to one another. They provide interesting insight when one is trying to work on the limitations of a given domain.

Many library classification systems were developed between 1804 and 1975 as an answer to increasing collections of data. As they served a similar purpose, most disappeared or were only confined to a limited territory, as in the case of the Chinese Library Classification in China. The two systems which are most used today are the Dewey classification system and the Universal Decimal Classification system, which was derived from the Dewey system (Holzem 1999: 90). The British National Library has opted for the Dewey classification system, which was created in 1876 by Melvil Dewey, an American philosopher with a special interest in education and social reform. One of the practical outcomes of his philosophical work was the creation of a classification system with a possible universal use. The advantage of this system, according to Dewey, was to "get absolute simplicity by using the simplest known symbols, the Arabic numerals as decimals [...] to number a classification of all human knowledge in print" (Sharma 2006: 3). Its success can be expressed in figures. It has been translated into over thirty languages, is used in the libraries of more than 135 countries, and is constantly revised to reflect trends in knowledge organisation (Singh 2011: 293).

Under this system, all publications can be classified into the ten main fields of knowledge identified by Dewey at the end of the nineteenth century: Generalia (000), Philosophy (100), Religion (200), Social Sciences (300), Languages (400), Pure Science (500), Technology (600), The Arts (700), Literature (800), History and Geography (900). Each of these disciplinary fields can then be divided into an infinite number of subsections by adding significant numbers behind this first figure. For instance, if we take Philosophy, is it divided into nine different sub-sections. Category 110 corresponds to Metaphysics, whereas category 120 corresponds to Epistemology. Within each of these sub-sections, one finds ten new subdivisions. Inside Metaphysics, 111 corresponds to Ontology, 113 corresponds to Cosmology, 115 corresponds to Time, etc. A large number of Dewey categories thus exist, and more are created every year. A very precise hierarchical relationship between each of these categories is symbolised by their numerical translation as the numerical relation between each figure symbolises a semantic relation between the different Dewey categories.

7 This purely hierarchical organisation has some disadvantages. Although all subjects can be included into this system with the creation of new branches, the hierarchical organisation tends to compartmentalise knowledge into small, unconnected topics rather than demonstrating the links that may exist between them. Interdisciplinarity can hardly be taken into account with this system. Other systems, like the colon classification developed by S. R. Ranganathan in India attempt to go beyond this problem by using facets, that is to say primary categories which give different types of information on each work. The Universal Decimal Classification system (UDC) provides a partial solution to this problem by using punctuation symbols to indicate different types of relationships between subjects. Yet, although UDC enables the expression of relationships between subjects, while the Dewey system does not, it remains monohierarchical in its structure, leading to a representation of interdisciplinarity which has its limits:

Monohiérarchique dans sa structure fondamentale, la CDU offre, au prix d'indices cependant très longs, la possibilité de regroupements par thèmes, de synthèse de certains sujets un peu à l'image d'une classification à facettes. En permettant la 
coordination de plusieurs indices (comme la mise en relation) elle offre la possibilité d'exprimer assez librement de nouveaux sujets. [...]. Cette possibilité ne remet cependant pas en cause la structure monohiérarchique de l'ensemble : tout sujet découle des dix classes fondamentales. [...] Comme toute classification monohiérarchique, elle impose une classe mère à partir de laquelle devra se développer les nouveaux indices. L'interdisciplinarité n'y est reconnue que comme processus ponctuel mais non génératif. (Holzem 1999: 106)

Looking at the environmental domain, an emerging specialised domain which is interdisciplinary by nature, through the lenses of a system which does not take into account interdisciplinarity as efficiently as the UDC, thus promises to be challenging.

\subsection{Dewey classes and environmental dictionaries at the British National Library}

9 To identify the different Dewey sub-sections in which environmental dictionaries may be found, the British National Library (BNL) seems an interesting starting point, given the size of its collections. To gather information, the BNL's online catalogue was used, entering the key words "environmental dictionary" into the search engine. The filter "Books" was used to make sure that all the articles and synopses about dictionaries were ruled out, leaving only the dictionaries themselves. This search gave ninety-one results. A second step was going through these results to eliminate all the dictionaries which contained the term "environment" in their title, when it was not used with an environmental meaning. ${ }^{2}$ For example, in expressions like "work environment" or "technological environment", "environment" is used to describe what surrounds a certain person or machine and influences the way in which he or it operates. Therefore, the term has nothing to do with environmental protection in such a context. There were also a few books in our first list which happened not to be dictionaries and which were removed. This left a corpus of seventy-eight books from which relevant statistics about the distribution of Dewey categories could be identified. However, to make sure no environmental dictionary had been left out, several other words from the environmental field were entered into the search engine: "environment dictionary", "climate change dictionary", "sustainable development dictionary", "green dictionary", "ecology dictionary" and "ecological dictionary". These searches provided six additional results, including one with no Dewey classification.

10 For each dictionary, information was collected in a table indicating title, author, date of publication and Dewey classification number. Unfortunately, thirteen dictionaries did not appear under any Dewey category ${ }^{3}$, which led us to exclude them from our corpus. From the titles, one obvious feature emerged: there would be different disciplinary orientations in these books as the titles themselves revealed. In some cases, terms like "environmental economics" or "environmental engineering" clearly signalled a specific disciplinary perspective on environmental issues. In other cases, the title was more general and did not suggest a disciplinary orientation. Yet even in the case of similarly named dictionaries, the variety of Dewey categories in which these books were classified suggested that, notwithstanding the title, there probably would be some disciplinary differences to note. To give a preliminary idea of this variety, Table 1 shows the number of dictionaries in each main Dewey class. 
Table 1 Number of dictionaries per Dewey Class

\begin{tabular}{|l|l|l|}
\hline Dewey Number & Dewey Title & Number of dictionaries at BNL \\
\hline 100 & Philosophy & 0 \\
\hline 200 & Religion & 0 \\
\hline 300 & Social Sciences & 46 \\
\hline 400 & Language & 0 \\
\hline 500 & Science & 14 \\
\hline 600 & Technology & 18 \\
\hline 700 & Arts \& Recreation & 0 \\
\hline 800 & Literature & 0 \\
\hline 900 & History \& Geography & 1 \\
\hline
\end{tabular}

11 Although five of the main Dewey classes do not contain any environmental dictionaries, four do. The best represented class is Social Sciences, but it is essential to note that, among social sciences, very different disciplines can be distinguished. In Figure 1, four different types of social sciences are distinguished where environmental dictionaries can be found. All the sections linked to social sciences are represented with shading, while the others are not.

Figure 1 Distribution of Dewey classes in the corpus

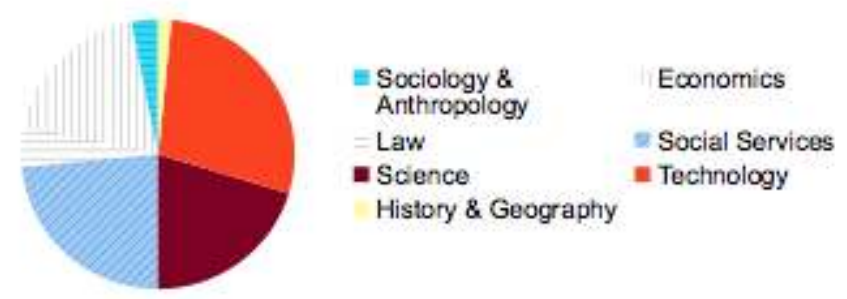

12 Figure 1 indicates the different sub-sections for Social Sciences: the first, comprising works on Sociology and Anthropology (301 à 309) ${ }^{4}$ includes two dictionaries, the second, Economics (330), includes twelve, the third, Law (340) includes three and the fourth, Social Services (360), includes fifteen. This preliminary overview of the diversity of the disciplinary classifications of environmental dictionaries in the BNL must be complemented with a more detailed study. Table 2 presents all the subcategories in social sciences, and the number of dictionaries in each sub-category. 
Table 2 Dewey sub-categories in Social Sciences

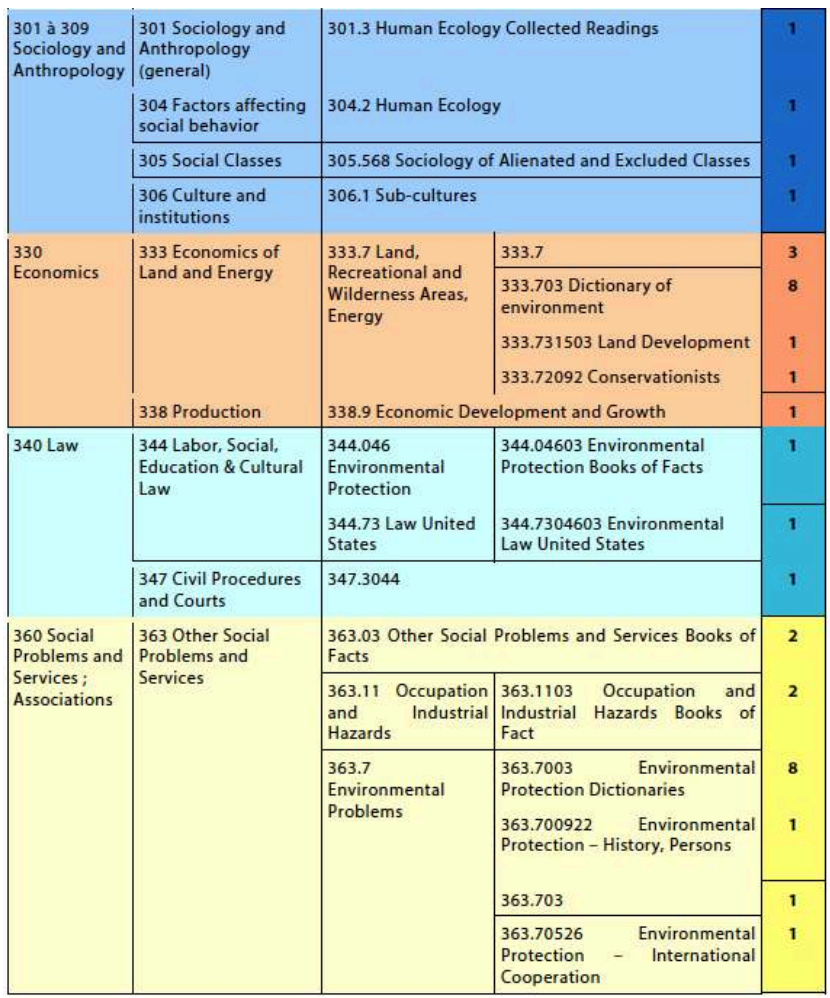

It is essential to note how varied the labels are if the table is taken as a whole. From the "Sociology of Alienated and Excluded Classes" to the "Economics of Land and Energy" or the "Economics of Appropriate Technology", there may well be many differences in disciplinary perspectives. Among the categories in the law class, such diverse labels as "Environmental Protection", "Environmental Law United States" and "Civil Procedures and Courts" can be quoted. On the contrary, what is striking about sub-categories in "Social Problems and Services; Associations" is that there is less variety as all the works are classified in 363 standing for "Other Social Problems and Services". Out of fifteen of the dictionaries classified there, eleven are in 363.7, which stands for "Environmental Problems", among which eight are in 363.7003, which stands for "Environmental Protection Dictionaries".

At this stage, a point can be raised: there is in fact a category in the Dewey classification system entitled "Environmental Protection Dictionaries". If this had been known from the start of the study, it is highly likely that only the dictionaries classified in this section would have been considered. Consequently, the seventy remaining dictionaries would have been missed out, which would have greatly undermined the results of this study. However, the existence of this category does raise the question of why only eight of the dictionaries on our list are classified under what appears to be an appropriately named sub-section. What then is specific to those dictionaries, and why were the others considered as not pertaining to this sub-section?

In Table 3, a detailed view of the classification of dictionaries in the Science class is given. 
Table 3 Dewey sub-categories in Science

\begin{tabular}{|c|c|c|c|}
\hline \multicolumn{3}{|c|}{500 Natural Sciences and Mathematics } & 1 \\
\hline $\begin{array}{l}540 \text { Chemistry } \\
\text { and Allied } \\
\text { Sciences }\end{array}$ & \multicolumn{2}{|l|}{ 540.3 Chemistry Dictionaries } & 1 \\
\hline \multirow{3}{*}{$\begin{array}{l}550 \text { Earth } \\
\text { Sciences }\end{array}$} & \multicolumn{2}{|l|}{550.3} & 1 \\
\hline & \multirow{2}{*}{$\begin{array}{l}551 \text { Geology, hydrology \& } \\
\text { meteorology }\end{array}$} & 551.48 Hydrology & 1 \\
\hline & & 551.603 Climatology and Weather & 1 \\
\hline \multirow{5}{*}{$\begin{array}{l}570 \text { Life } \\
\text { Sciences; } \\
\text { Biology }\end{array}$} & 570 Biology & 570.3 Biology dictionary & 1 \\
\hline & \multicolumn{2}{|l|}{574 Not assigned } & 3 \\
\hline & \multirow[t]{2}{*}{577 Ecology } & 577.024344 & 1 \\
\hline & & 577.03 Ecology Dictionaries & 3 \\
\hline & $\begin{array}{l}579 \text { Microorganisms, } \\
\text { Fungi \& Algae }\end{array}$ & $\begin{array}{l}579.17 \text { Specific Topics in Natural History of } \\
\text { Microorganisms, Fungi, Algae }\end{array}$ & 1 \\
\hline
\end{tabular}

The variety of categories is striking. No predominant sub-category can be identified. The relevant disciplines are presented as: natural science, chemistry, earth sciences and life sciences. One interesting label can be highlighted: the "Ecology Dictionaries" (577.03), though only three dictionaries are classified under this seemingly welladapted category. Finally, Dewey labels for environmental dictionaries in Technology were identified (see Table 4).

Table 4 Dewey sub-categories in Technology

\begin{tabular}{|c|c|c|c|}
\hline $\begin{array}{l}610 \text { Medicine } \\
\text { \& Health }\end{array}$ & 616 Diseases & $\begin{array}{l}616.98 \text { Non-communicable Diseases and } \\
\text { Environmental Medicine }\end{array}$ & 2 \\
\hline \multirow{3}{*}{$\begin{array}{l}620 \\
\text { Engineering }\end{array}$} & \multicolumn{2}{|l|}{624 Civil Engineering } & 1 \\
\hline & \multirow{2}{*}{$\begin{array}{l}628 \text { Sanitary and } \\
\text { Municipal } \\
\text { Engineering }\end{array}$} & 628 & 2 \\
\hline & & $\begin{array}{l}\text { 628.03 Environmental Engineering } \\
\text { 628.162 Sanitary Engineering - Water Supply }\end{array}$ & 1 \\
\hline \multirow{2}{*}{$\begin{array}{l}630 \\
\text { Agriculture }\end{array}$} & \multicolumn{2}{|l|}{630.3} & 1 \\
\hline & $\begin{array}{l}631 \text { Techniques, } \\
\text { Equipment \& } \\
\text { Materials }\end{array}$ & 631.4 Soil Science & 1 \\
\hline $\begin{array}{l}660 \text { Chemical } \\
\text { Engineering }\end{array}$ & $\begin{array}{l}668 \text { Technology of } \\
\text { Other Organic } \\
\text { Products }\end{array}$ & 668.6 Agricultural Chemical & 1 \\
\hline
\end{tabular}

17 Two appear in Medicine and Health (610), with a category which is recognisably part of our field of interest: "Non-communicable diseases and environmental medicine". Nine are classified in Environmental Engineering, which unexpectedly is the category where most environmental dictionaries at the BNL can be found. A single dictionary is classified in the History and Geography section, more precisely in "Geography and Travel" (910.3).

What can be said about the general view provided with these tables is that no category here seems misplaced or surprising. It is well known that sociology, economics, law, geography and social services are all concerned with environmental issues. Likewise, it is not unexpected that environmental terminology should be used in the fields of life sciences, earth sciences and chemistry. These are needed to understand environmental 
problems. And these problems could not be solved without the help of medicine, engineering and agriculture. But what is more difficult to understand is that, from our perspective, they pertain to a group of dictionaries that can be considered as belonging to a single category, because they all deal with terms related to the protection, preservation or regeneration of the environment. And yet, they do not appear as a group in the Dewey classification system. One of the reasons behind these differences in classification may appear in their titles, as they sometimes mention a disciplinary orientation. Identifying key words belonging to different disciplines in the titles and considering in what ways they match or do not match the disciplines identified for each work using the Dewey number should enable us to shed light on this question.

\section{Dewey classifications and titles}

\subsection{Disciplinary key words in titles}

Environmental issues can be considered from many different disciplinary perspectives and this is quite apparent in the list of dictionaries in the BNL catalogue. Many key words pertaining to other disciplinary fields can be identified. In some cases, these key words provide a good clue for understanding the reason behind the Dewey classification of the dictionaries. The titles of different dictionaries were listed in a Table (see Appendix), ${ }^{5}$ highlighting ${ }^{6}$ the key words of interest that they contain, together with the relevant Dewey category. The aim was to determine whether there was a coherent relationship between the key words and the Dewey category.

In the first three dictionaries, the titles comprise key words linked to the economic field: therefore, it is not surprising to find these dictionaries in the Economics section. In two disciplines from the Science section, one can also find a good match between key words in the title and the Dewey category: Chemistry and Earth Sciences. The correlation between key words and Dewey categories is also high in most of the dictionaries classified in Technology, whether it be in Agriculture, Soil Science or Agricultural Chemicals. Furthermore, all the dictionaries that have "engineering" or "technology" in their titles are classified in Engineering. Finally, the dictionary which contains "water" in its title is classified in "Sanitary Engineering - Water Supply" and the one with "geography" in its title in "Geography and Travel".

21 However, this correlation between key words and Dewey categories was not observed in the whole corpus. Among dictionaries with key words linked to the medical field, only two are classified in the "Non-communicable diseases and environmental medicine" (616.98003). The remaining three are classified in the section entitled "Environmental Protection Dictionaries" (363.7003). In the case of law, an exception can also be found with the Dictionary of Environmental Science for Lawyers (Battersby 1997) which appears in "Ecology" (577). It is quite an interesting case where a double specialisation is mentioned in the title: specialisation of the subject on one hand, presented as "environmental science" and specialisation of the readership on the other hand, "for lawyers". Scanning this dictionary, the reader soon realises that the main focus is legal. When it comes to defining the term "environment," for instance, all the content is drawn from legal texts, clearly underlining the relevance of law to the issue. This perspective is also highlighted in the preface: "It is not only aimed at practicing lawyers, but also law students who have opted to study environmental law. It may also 
be of some use to environmental scientists who wish to put their work and studies into a legal and policy context" (Battersby 1997: x). Because the legal orientation is preponderant in this dictionary, it is rather surprising to find it classified in the Ecology section rather than in the Legal section.

In most cases, as seen above, the titles of dictionaries classified in the same Dewey section are quite similar. They contain key words which are synonymous or reflect a similar understanding of environmental issues. Yet there is one Dewey category which can by no means be described as containing dictionaries which are similarly entitled. This is the "Environmental Protection Dictionaries" section. In this section, one finds several dictionaries with words in the title that suggest very different content: "global environmental governance", "historical", "health", "medicine". It is thus quite difficult to understand why these different dictionaries are classified together. It might be necessary to turn to their content to try and find an explanation, which is done in the third part of this article.

\subsection{Dictionaries with titles presenting no disciplinary orientation}

23 Although in the previous section many examples were given of dictionaries whose titles contain key words which point to the adoption of a specific disciplinary perspective on environmental issues, it is not the case for all the works contained in the corpus. Some of them just contain the term "environmental science". The definition of "environmental science" is ambiguous. Park (2007) defines it as "the interdisciplinary study of environmental systems, how they operate, how they interact with people, and how people interact with them" (2007: 154). It is quite a general definition, which does not give any insight on the disciplines involved. In fact, environmental science can refer to economy, biology, geology, law and many different sciences when they are applied to environmental issues. It gives information on the subject of study but not really on the methodology adopted to study it. The ambiguity caused by the polysemy of the term "environmental science" is well reflected in the corpus. The following list of titles containing the term can be quoted: The Facts on File Dictionary of Environmental Science (Stevenson \& Wyman 1991), Collins Reference Dictionary: Environmental Science (Jones 1990), Longman Dictionary of Environmental Science (Lawrence et al. 1998), The Dictionary of Environmental Science and Engineering (Pfafflin et al. 2008), The Dictionary of Ecology and Environmental Science (Art 1993). Considering how closely related these different titles are, one could expect to find them in neighbouring Dewey sections. Yet, this is far from being the case. Dictionaries by Pfafflin et al. (2008) and Stevenson \& Wynon (1991) are classified in "Environmental Engineering". Dictionaries by Lawrence et al. (1998) and Jones (1990) appear in "Environmental Economics". A dictionary by Art (1993) pertains to the class of "Environmental Protection Dictionaries". Quite obviously, the term "environmental science" does not refer to the same kind of science in these titles. Environmental economics and environmental engineering are very different sciences adopting very different methodologies to study environmental problems. The same selection of terms on environmental issues could not be made according to whether they are taken from an economic perspective or from an engineering perspective. The title does not reflect these specificities, nor does it enable the user to distinguish between these different dictionaries. 

environmental field without another disciplinary orientation. There are nineteen of these in all. To give a few examples, the Dictionary of Environmental Terms (Gilpin 1976) is classified in "Sociology and Anthropology", The Green Dictionary: Key Words, Ideas and Relationships for the Future (Johnson 1991) in "Environmental Economics" and The Environment Dictionary (Kemp 1998) and A Dictionary of Environment and Conservation (Park 2007) in "Environmental Protection Dictionaries". Dewey classifications for this group of dictionaries are shown in Table 5.

Table 5 Number of dictionaries which mention only the environmental field and not another discipline in their title

\begin{tabular}{|l|l|}
\hline Dewey Category & Number of Dictionaries \\
\hline Law & 1 \\
\hline Sociology & 1 \\
\hline Social organisations & 6 \\
\hline Economy & 4 \\
\hline Science & 1 \\
\hline Life Sciences & 6 \\
\hline
\end{tabular}

What can be concluded about this inquiry into the links between the key words in the titles and the Dewey classifications of the dictionaries is that although key words in titles may be important criteria to understand the principles leading to classification choices, one should also look for other factors. Of course, it is quite natural that titles should only hint at differences between dictionaries. The role of a title is to give indication about the content of a given dictionary, but it can rarely be considered as sufficient to inform readers about the nature of a work. It may then be useful to investigate the content of the dictionaries, so as to gain better understanding of their specificities.

\section{Dewey classifications and content}

\subsection{The selection of terms}

Considering the limited scope of the present article, a view of the content of all the environmental dictionaries found in the BNL will not be provided. To tackle the questions that we raised, it was necessary to select a representative sample from the corpus. The first question could be that of the selection of terms in the dictionary and whether this selection seems coherent with the Dewey classification. It may be fruitful to compare lists of terms from different dictionaries to see whether they are similar, or whether the specificities of each list correlate with titles and Dewey classifications. Yet, rather than trying to gather data about dictionaries classified in all the different Dewey classes, it may be more telling to select and compare some that have key words from 
the same discipline. As mentioned earlier, there are some dictionaries with health key words which are classified in the health section and some which are not. This difference in classification may be due to the fact that the content of the two dictionaries classified in Health is much more medical than the content of the dictionary classified in Environmental Protection Dictionaries. With this in mind, the author selected the Dictionary of Environmental and Occupational Medicine (Ohrbach 2001), which is classified in "Medicine and Health" (610) and the Lewis Dictionary of Occupational and Environmental Safety and Health (Vincoli 1999) which belongs to "Environmental Protection Dictionaries". So as to present examples of other disciplinary orientations signalled in the title, she also selected one work classified in Economics, A Dictionary of Environmental Economics (Markandya 2001), one work classified in Earth Sciences, the Dictionary of Global Climate Change (Maunder 1994) and one work classified in "Social Organisations", more precisely in a sub-section entitled "Environmental protection - international cooperation" (363.70526): Dictionary and Introduction to Global Environmental Governance (Meganck \& Saunier 2009). Then she selected two dictionaries with "environmental science" in the title, The Dictionary of Ecology and Environmental Science (Art et al. 1993) and The Facts on File Dictionary of Environmental Science (Stevenson \& Wyman 1991) and three dictionaries with only environmental key words in the title, The Dictionary of Environment and Sustainable Development (Gilpin 1996), The Environment Dictionary (Kemp 1998) and the A Dictionary of Environment and Conservation (Park 2007). The sample may thus be considered as being representative of the whole corpus, with some examples of dictionaries with a disciplinary orientation in the title, two examples of dictionaries with the term "environmental science" in the title, and three dictionaries containing only key words linked to the environmental field in their title.

To compare the content of these dictionaries, the author conducted a close analysis of the selection of terms starting with the letter $\mathrm{A}$ in each of them with a view to determining whether the selection of terms was similar, whatever the title, and whether the specificities of each list could shed light on the principles for the Dewey classification.

Table 6 Selection of words representative of a discipline other than the environmental field in three dictionaries

\begin{tabular}{|l|l|l|l|}
\hline Title & $\begin{array}{l}\text { Key word in } \\
\text { title }\end{array}$ & $\begin{array}{l}\text { Dewey } \\
\text { Class }\end{array}$ & Specific terms \\
\hline $\begin{array}{l}\text { A Dictionary of } \\
\text { Economics }\end{array}$ & $\begin{array}{l}\text { environmental } \\
\text { economics }\end{array}$ & 333.703 & $\begin{array}{l}\text { Abatement cost, absolute scarcity, accommodating } \\
\text { technocentrism, adaptive expectation, adaptive } \\
\text { management, adaptive policy, additionality, } \\
\text { adjusted income, aesthetic externalities, aesthetic } \\
\text { (historical and cultural valuation), affluence, } \\
\text { aggregate abatement information, aggregate } \\
\text { demand, aggregate production function, aggregate } \\
\text { supply, acariasis, acaricide, acarid, Ace bandage }\end{array}$ \\
\hline
\end{tabular}




\begin{tabular}{|c|c|c|c|}
\hline $\begin{array}{l}\text { Dictionary of } \\
\text { Environmental } \\
\text { and Occupational } \\
\text { Medicine }\end{array}$ & $\begin{array}{l}\text { environmental } \\
\text { and occupational } \\
\text { medicine }\end{array}$ & 616 & $\begin{array}{l}\text { Abacterial, abasia, abdomen, abdominal aorta, } \\
\text { abdominal cavity, abdominal pain, abduct, } \\
\text { abduction, ABG (Arterial Blood Gas), abient, ability, } \\
\text { ablation, abnormal behavior, ABO blood groups, } \\
\text { abortus fever, ABP (Arterial Blood Pressure) } \\
\text { abrasion, absenteeism }\end{array}$ \\
\hline $\begin{array}{l}\text { Lewis Dictionary } \\
\text { of Occupational } \\
\text { and } \\
\text { Environmental } \\
\text { Safety and Health }\end{array}$ & $\begin{array}{l}\text { occupational and } \\
\text { environmental } \\
\text { safety and } \\
\text { health }\end{array}$ & 363.11 & $\begin{array}{l}\text { A-scale sound pressure level, A-weighted network, } \\
\text { abbreviated injury scale, abdomen, abdominal } \\
\text { cavity, abdominal circumference, abdominal depth, } \\
\text { abdominal extension circumference, abdominal } \\
\text { extension depth, abdominal extension height, } \\
\text { abdominal extension level, abdominal extension to } \\
\text { wall, abdominal skinfold, abdominal wall, } \\
\text { abdominoscopy, abducens, abducent muscles, } \\
\text { abduct, abduction angle, abductor, ability, ab } \\
\text { inconvenient, ab initio, ablate, able-bodied, } \\
\text { ABLEDATA, abnormal reading, abnormal time, abort, } \\
\text { above elbow, above knee, abrade, abrasion, abcess, }\end{array}$ \\
\hline
\end{tabular}

In the dictionaries represented in Table 6, it is obvious that the title and Dewey classification are consistent with the selection of words. Concerning the two dictionaries which have health key words in their title, it is important to highlight that there is a difference in their Dewey classification, as mentioned earlier. In this table, the results for the first dictionary, classified in the health category (616) can be compared with a dictionary which has medical terms in its title but is not classified in a medical Dewey category. It appears that just as many, or even more, specialised medical terms appear in this second dictionary, which is not consistent with the Dewey class selected for it. In some cases, all the terms which appear in the dictionary pertain to the environmental field.

Table 7 Example of words found only in one dictionary which are representative of the environmental field

\begin{tabular}{|l|l|l|}
\hline $\begin{array}{l}\text { Key word in } \\
\text { title }\end{array}$ & $\begin{array}{l}\text { Dewey } \\
\text { Class }\end{array}$ & Specific terms \\
\hline $\begin{array}{l}\text { environmental } \\
\text { science }\end{array}$ & 628 & $\begin{array}{l}\text { aa flow, Abalone alliance, abandoned site, abandoned well, abatement, } \\
\text { Abbey Edwards, abiotic, abrasive blasting, abscission, absolute error, } \\
\text { absolute humidity, absolute pressure, absolute temperature, absolute } \\
\text { zero, absorbance, absorbed dose, absorber, absorption, absorption band, } \\
\text { absorption coefficient, absorption factor, absorption spectrum, } \\
\text { absorption tower, absorptivity, abyssal zone, acceleration, accelerator, } \\
\text { acceptable daily intake }\end{array}$ \\
\hline
\end{tabular}




\begin{tabular}{|c|c|c|}
\hline $\begin{array}{l}\text { global climate } \\
\text { change }\end{array}$ & $551.603^{8}$ & $\begin{array}{l}\text { Abiotic, ablation, absorption, absorption band, absorption capacity, } \\
\text { absorption of radiation, ACCAD (Advisory Committee on Climate } \\
\text { Applications and Data of the WMO World Climate Programme) } \\
\text { acclimatization, accumulated temperature, acid rain, ACMAD (African } \\
\text { Centre of Meteorological Applications for Development), actinometer, } \\
\text { actual evaporation, actual evapotranspiration, adaptation, adaptation } \\
\text { strategies, adiabiatic process, advection, Advisory Group on Greenhouse } \\
\text { Gases, aerobiology, aerology, aerosol propellant, aerosols, aerosols } \\
\text { (global distribution of), aerosols (global sources of), afforestation, AFOS, } \\
\text { African Centre for Meteorological Applications for Development }{ }^{9}\end{array}$ \\
\hline
\end{tabular}

What can be noted in Table 7 is that although the Dewey class of the first dictionary would suggest the presence of key words specific to Engineering, ${ }^{10}$ such key words do not materialise. All the terms in the third column of the table could be present in any type of environmental protection dictionary. They are not specific to an environmental engineering perspective. If we look at the last line of the table, the situation is somewhat different. One can find terms which are different from the other lists of A terms in different dictionaries but their specificity is linked to one particular theme: climate change. This can be seen as a sub-field of the environmental domain and thus there is a focus on this particular environmental issue. When one considers this selection of terms, it would not have been surprising to have this dictionary classified with other environmental protection dictionaries.

This small sample from the corpus enables the author to conclude that a selection of terms included in different dictionaries is not a sufficient criterion to understand the principles used to index them. Although there are several examples where the selection of terms reflects the Dewey category under which the dictionary appears, one can still wonder why one of the environmental health dictionaries was classified in "Health and Medicine", whereas the other was classified in "Environmental Protection Dictionaries," or why the dictionary containing "environmental science" in its title appears in "Environmental Engineering" (628). Concerning the dictionaries where the titles had only environmental key words, as expected, the selection of terms was representative of this field as a whole, which is why they are not included in the above table.

\subsection{The content of the definitions}

31 Although a selection of terms included in a dictionary seems a good criterion to measure its disciplinary specialisation, looking at the definitions of terms may offer further information. Some words with the same form receive different definitions in different disciplines. Besides, the words chosen to define a term can be revealing of a disciplinary orientation. Consequently, the second part of this study of content focuses on the definitions of a few selected words and on their differences from one dictionary to the other.

The first term considered is "acid rain". It is defined in a very similar way in all the dictionaries under study, although definitions vary greatly in length, ranging from six sentences to four pages. The similarities are such that it is possible to list the semantic features of a prototypical definition of the word. In all cases, the two following features 
are mentioned: (i) it it presented as rain which has an acidity above the normal level (the approximate value from which rain is considered as acid is on average a $\mathrm{pH}$ of 5 or below); (ii) this acidity is presented as being caused by sulphur oxides and nitrogen oxides. In six definitions out of ten, the sulphur oxides and nitrogen oxides are pointed as being the result of anthropogenic activity, power stations and transportation systems being the most quoted examples. In five out of ten definitions, details are given about the damage caused by acid rain in the environment on various elements like aquatic organisms, vegetation, soil, but also limestone and marble buildings. Finally, only in three out of ten of our dictionaries are measures to curtail those harmful effects mentioned in the definitions. What may be interesting to note is that the three dictionaries which do mention these measures (Gilpin 1996; Kemp 1998; Park 2007) are all classified in the "Environmental Protection Dictionaries" section. Thus, although the definition of "acid rain" does not help to distinguish different dictionaries according to the disciplinary orientation, as they all propose similar content (with a difference in the length of development), one hypothesis which could be put forward would be that in dictionaries classified in the "Environmental Protection Dictionaries" section, a focus on protection measures is prevalent.

Concerning the term "adaptation", it can first be stated that there is much less consensus in the definitions offered by the selection of dictionaries. It would be much more difficult to propose elements composing a prototypical definition in this case because of the large variety of content observed. However, what can be identified are disciplinary orientations. The discipline indicated thanks to the key words in the title and to the Dewey number also is denoted in the content of some of these definitions. For example, in the Dictionary of Environmental Economics (Markandya 2001), an economic focus on the issue is obvious. Adaptation is not only considered from the point of view of natural organisms adapting to their environment, which could be the definition one would tend to expect in an environmental dictionary. The adaptation of the economic system to changed environmental conditions is also presented as an essential semantic feature of the term. The economic consequences of adaptation are also highlighted and said to "considerably reduce the costs of climate change" (2001:3). In the dictionary that has "global environmental governance" in its title, one finds a political orientation in the definition of "adaptation," with reference to "policies and actions that minimise adverse effects of climate change" (Meganck \& Saunier 2009: 49). Other definitions are more neutral, focusing only on adaptation of organisms to their habitat and presenting the process in more or less technical terms, with different types of examples given.

As was the case with "adaptation", it is not possible to identify a prototypical definition for the term "absorption". This term is polysemous and its polysemy is mentioned in four out of ten dictionaries. It seems quite interesting that it should be selected as a key term in most of the dictionaries considered here, and yet that the term should not always refer to the same process. Different concepts can be referred to using the same term, and the following examples show that in some cases the absorption referred to happens in the human body, in others it is the soil which absorbs and in other cases what is described is a voluntary process caused by man to remove pollution. The choice of definition seems influenced by the disciplinary orientation of the dictionary. Thus, in the two dictionaries with a medical orientation, a medical or physiological definition of the term is given, which has nothing to do with environmental issues. In the Lewis Dictionary of Occupational and Environmental Safety and Health (Vincoli 1999) for instance, 
among other definitions to the term, the following is mentioned: "The process by which porous tissues such as the skin and intestine walls permit passage of liquids and gases into the bloodstream" (1999: 6). In the Dictionary of Environmental and Occupational Medicine (Ohrbach 2001), one can read the following: "A route of entry into the body through broken or unbroken skin" (2001:3). The most general definition of absorption is given in three dictionaries: The Environment Dictionary which defines it as "the assimilation of one substance by another" (Kemp 1998: 1); the Dictionary of Environment and Sustainable Development, which defines it as "the passing of a substance or force into the body of another substance" (Gilpin 1996: 1); A Dictionary of Environment and Conservation which defines it as "the penetration of one substance into or through another, such as the absorption of water into soil, or the uptake of water and nutrients by a cell of organisms which absorbs them" (Park 2007: 2). Four dictionaries mention absorption as a counter-pollution measure. Firstly, the Dictionary of Global Climate Change focuses only on this understanding of the word: "[r]emoval or radiation from an incident solar or terrestrial beam, with conversion of another form of energy: electrical, chemical or heat" (Maunder 1994: 1). Secondly, in The Environment Dictionary (Kemp 1998), one can highlight the following sentences on this theme:

At the local scale, absorption has a major role in pollution control. The removal of noxious gases from flue gas emissions is commonly accomplished through absorptions and absorbent materials such as peat are frequently used to soak up liquid spills. (1998: 1)

Thirdly, A Dictionary of Environment and Conservation contains the following explanation: "A way of containing an oil spill, in which oil is absorbed into special materials from which it can be squeezed out for reuse or disposal" (Park 2007: 2). Finally, in the Lewis Dictionary of Occupational and Environmental Safety and Health (Vincoli 1999), the sixth definition, entitled "environmental", is the following: "The adhesion of molecules of gas, liquid or dissolved solids to a surface. Used as an advanced method of treating in which activated carbon removes organic matter from wastewater" (1999: 7). What is noticeable is that two of the dictionaries which mention this semantic feature also mentioned protective measures in the definition on acid rain. They are both classified in the Dewey section of "Environmental Protection Dictionaries" (363.7003). In the dictionaries which have an economic orientation, the term absorption as such does not figure but the notion does, as one can find the term "absorptive capacity", which has common semantic features. Yet, in this case, the absorption process is mentioned from an economic point of view, as demonstrated in these definitions of the term: "[t]he ability of the environment to assimilate waste products from the economy" (Grafton 2001: 1) and "[t]he capacity of an environment to assimilate waste products from an economic activity" (Meganck \& Saunier 2009: 48).

This study of the content of the definitions suggests that the disciplinary orientations of the dictionaries, identified thanks to the key words in the title, do have an impact on definitions. Definitions show variations which are clearly influenced by different disciplinary perspectives. Also of note is the fact that the dictionaries which are classified in the Dewey section "Environmental Protection Dictionaries" seem more likely to mention environmental protection measures than the others. However, the patterns revealed above also show irregularities and do not permit to give a clear-cut answer to the question of what the logic behind the Dewey classifications of environmental dictionaries at the BNL is. More work is needed to explore the paths opened here. 


\section{Conclusion} easy task. It has been the author's ambition in this article to reveal some of the logic behind the classification choices. Actually, the titles and content of the dictionaries sometimes demonstrate a clear disciplinary orientation, which could explain that they were classified in a section other than the "Environmental Protection Dictionaries". However, it is sometimes difficult to find coherence in the choices, as some closely related works have not been classified in the same section. It seems a pity, for the sake of clarity, that there should not be a large environmental protection section among the Dewey classes. This section would then be divided into different sub-sections like environmental economics, environmental engineering, environmental health, etc. The work of people who specialise in the environmental field would prove much easier if all the works they need to gain better understanding of the field were not presented as totally separate entities. The limitations to the Dewey classification system which this study has underlined have been identified in other studies. Despite its popularity, criticism of the Dewey classification system is by no means rare. One of its major drawbacks is that it does not easily integrate structural changes in the organisation of knowledge.

It has been shown that the Dewey classification system can be claimed to be oldfashioned. Yet, classification systems do not evolve easily. It is the force of the Dewey system as well as its weakness that its overarching structure has been able to absorb many new categories which are included as multiple sub-categories added to the system each year. This means that the system is enriched over time and yet remains quite stable and easy to use. It is a tool that the user needs to benefit from the resources of a library, and even if it may not seem to be the most efficient, it is nevertheless indispensable. It therefore needs to be composed with and mastered. One way of helping the development of knowledge on environmental questions and making sure that there are more and more experts capable of adopting a global perspective on environmental issues would be to continue this work of mapping the different disciplines involved with these issues. Further studies are needed to address these issues, with a view to providing readers with guidelines with which to find their bearings in the complex world of environmental dictionaries. Turning to Dewey classifications is a useful tool for anyone trying to map a specialised domain. If it confirms its complexity, it also provides some information about the borders between its different sub-sections, borders that can be crossed and made to evolve, but whose existence should not be denied.

\section{BIBLIOGRAPHY}

Art, Henry W. et al. 1993. The Dictionary of Ecology and Environmental Science. New York: H. Holt. 
Ayres, David and Desmond Hellier. 1998. Dictionary of Environmentally Important Chemicals. London: Blackie Academic \& Professional.

Battersby, Stephen. 1997. Dictionary of Environmental Science for Lawyers. Chichester: Wiley. Boisvert, Raymond D. 1998. John Dewey: Rethinking our Time. New York: State University of New York Press.

Donahue, Roy L. and Frederick R. Troeh. 2003. Dictionary of Agricultural and Environmental Science. Iowa: Iowa State Press.

Dury, Pascaline. 2006. "La dimension diachronique en terminologie et en traduction specialisée : le cas de l'écologie”. In Candel, D. \& F. Gaudin (eds.), Aspects diachroniques du vocabulaire. Mont Saint Aignan, France: Publications des Universités de Rouen et du Havre, 109-124.

Dury, Pascaline. 2007. "La déterminologisation du formant eco- et la terminologisation de l'adjectif carbon neutral un aperçu diachronique de la migration des termes". In Actes de la Conférence TIA'07 - 7e Conférence "Terminologie et Intelligence Artificielle". Grenoble: Presses Universitaires de Grenoble, 61-70.

Dzhamalov, Roald G. and Yurii V. Safronov. 1998. Elsevier's Dictionary of Geoenvironment and Natural Disasters. Amsterdam, Oxford: Elsevier.

Fill, A. \& P. Mühlhäusler (eds.). 2001. The Ecolinguistic Reader - Language, Ecology and Environment. London: Continuum.

Fløttum, Kjersti. 2010, “A linguistic and discursive view on climate change discourse”. ASp 58, 19-37.

Gilpin, Alan. 1976. Dictionary of Environmental Terms. London: Routledge and Kegan Paul.

Gilpin, Alan. 2000. Dictionary of Environmental Law. Chichester: Wiley.

Grafton, Quentin R. et al. 2001. A Dictionary of Environmental Economics. Cheltenham: Elgar.

Grafton, Quentin R. et al. 2012. A Dictionary of Climate Change and the Environment: Economics, Science and Policy. Cheltenham: Edward Elgar.

Gregorich, Edward G. et al. 2001. Soil and Environmental Science Dictionary. London: CRC Press.

Holzem, Maryvonne. 1999. Terminologie et documentation : pour une meilleure circulation des savoirs. Paris: ADBS Éditions.

Holzem, Maryvonne. 2006. “L'organisation des connaissances à l'ère du village planétaire : un point de vue global sur le monde". Matériaux pour l'histoire de notre temps 82/2, 82-86.

Jalenques-Vigouroux, Béatrice. 2006, “Dire l'environnement : le métarécit environnemental en question". Thèse en Sciences de l'information et communication, Université Paris 4.

Johnson, Colin. 1991. The Green Dictionary: Key Words, Ideas and Relationships for the Future. London: Optima.

Jones, Gareth et al. 1990. Collins Reference Dictionary: Environmental Science. London: Collins.

Kemp, D. David. 1998. The Environment Dictionary. London: Routledge.

King, James J. 1995. The Environmental Dictionary and Regulatory Cross-reference. Chichester: WileyInterscience.

Koren, Herman. 2003. Illustrated Dictionary and Resource Directory of Environmental and Occupational Health. Boca Raton, FL; London: Lewis. 
Laffont, Hélène and Jean-Louis Trouillon. 2013. "La recherche en anglais scientifique et la revue ASp : retour sur vingt ans de publications (1993-2012). ASp 63, 113-158.

Lawrence, Eleanor et al. 1998. Longman Dictionary of Environmental Science. Harlow: Longman. Lee, C. C. 1997. Dictionary of Environmental Legal Terms. New York, London: McGraw-Hill. Libaert, Thierry. 2004. Communication : la nouvelle donne. Paris: Pearson Education France. Libaert, Thierry. 2008, Le développement durable. Paris: Dunod.

Markandya, Anil. 2001. Dictionary of Environmental Economics. London: Earthscan Publications. Maunder, William John. 1994. Dictionary of Global Climate Change. London: UCL Press.

Meganck, Richard A. and Richard E. Saunier. 2009. Dictionary and Introduction to Global Environmental Governance. London: Earthscan Publications.

Mühlhäusler, Peter. 2005. Language of Environment, Environment of Language. London: Battlebridge. Myerson, George and Yvonne Rydin. 1996. The Language of Environment: A New Rhetoric. London: Taylor \& Francis Group.

Nanogens International. 1982. Nanogen Index 2: A dictionary of agricultural chemicals and environmental contaminants. Bournemouth: Nanogens International Europe.

Nicolas, Adrien G. 2008. Processing Water, Wastewater, Residuals, and Excreta for Health and Environmental Protection: An encyclopedic dictionary. Chichester: Wiley.

Ohrbach, Karl Heinz. 2001. Dictionary of Environmental and Occupational Medicine. Chichester: Wiley. Palmer, Joy. 2000. Questions Dictionary of Geography \& Environment. Birmingham: Questions Publishing Company.

Park, Chris C. 2007. A Dictionary of Environment and Conservation. Oxford: Oxford University Press. Pfafflin, James R. et al. 2008. The Dictionary of Environmental Science and Engineering. London: Routledge.

Pfannkuch, Hans-Olaf. 1990. Elsevier's Dictionary of Environmental Hydrogeology. Amsterdam; Oxford: Elsevier.

Schwartz, Alan M \& Edward R. Wells. 1997. Historical Dictionary of North American Environmentalism. Lanham, MD, London: Scarecrow.

Sharma, Chandra Kant. 2006. Practical Handbook of Dewey Decimal Classification. New Delhi: Atlantic Publishers \& Distributors Ltd.

Singh, Shivendra. 2011. The Theory and Practice of the Dewey Decimal Classification System. New Delhi: Gyan Books Ltd.

Stevenson, L. Harold and Bruce Wyman. 1991. The Facts on File Dictionary of Environmental Science. New York: Facts on File.

Van Der Yeught, Michel. 2009. "Structurer l'anglais de la bourse : une approche des langues de spécialité par la spécialité”. Mémoire de synthèse présenté pour l'Habilitation à diriger des recherches. Bordeaux: Université Victor-Segalen Bordeaux 2.

Vincoli, Jeffrey W. 1999. Lewis Dictionary of Occupational and Environmental Safety and Health. Boca Raton: Lewis Publishers.

Wüster, Eugen. 1968. The Machine Tool: An interlingual dictionary of basic concepts. London: Technical Press. 


\section{APPENDIXES}

\section{Dictionaries and Dewey category}

\begin{tabular}{|c|c|}
\hline Titles of Dictionaries & Dewey Category \\
\hline A Dictionary of Environmental Economics (Markandya 2001) & 330 Economics \\
\hline Dictionary of Environmental Economics (Grafton et al. 2001) & 330 Economics \\
\hline $\begin{array}{l}\text { A Dictionary of Climate Change and the Environment: Economics, } \\
\text { Science and Policy (Grafton et al. 2012) }\end{array}$ & 330 Economics \\
\hline $\begin{array}{l}\text { Dictionary of Environmentally Important Chemicals (Ayres \& } \\
\text { Hellier 1998) }\end{array}$ & 540 Chemistry \\
\hline $\begin{array}{l}\text { Elsevier's Dictionary of Geoenvironment and Natural Disasters } \\
\text { (Dzhamalov \& Safronov 1998) }\end{array}$ & 500 Earth Sciences \\
\hline $\begin{array}{l}\text { Elsevier's Dictionary of Environmental Hydrogeology (Pfannkuch } \\
\text { 1990) }\end{array}$ & 500 Earth Sciences \\
\hline Dictionary of Global Climate Change (Maunder 1994) & 500 Earth Sciences \\
\hline $\begin{array}{l}\text { Dictionary of Agricultural and Environmental Science (Donahue \& } \\
\text { Troeh 2003) }\end{array}$ & 630 Agriculture \\
\hline Soil and Environmental Science Dictionary (Gregorich et al. 2001) & 631.4 Soil Science \\
\hline $\begin{array}{l}\text { Nanogen Index 2: A Dictionary of Agricultural Chemicals and } \\
\text { Environmental Contaminants (Nanogens International 1982) }\end{array}$ & 668.6 Agricultural Chemicals \\
\hline Environmental Engineering Dictionary (Lee 2005) & $\begin{array}{ll}628.03 & \text { Environmental } \\
\text { Engineering } & \end{array}$ \\
\hline $\begin{array}{l}\text { Environmental Engineering Dictionary and Directory (Pankratz } \\
\text { 2000) }\end{array}$ & $\begin{array}{ll}628.03 & \text { Environmental } \\
\text { Engineering } & \end{array}$ \\
\hline Concise Dictionary of Environmental Engineering (Pankratz 1996) & $\begin{array}{ll}628.03 & \text { Environmental } \\
\text { Engineering } & \end{array}$ \\
\hline $\begin{array}{l}\text { The Dictionary of Environmental Science and Engineering } \\
\text { (Pfafflin et al. 2008) }\end{array}$ & $\begin{array}{l}628 \text { Sanitary and Municipal } \\
\text { Engineering }\end{array}$ \\
\hline $\begin{array}{l}\text { Routledge German Dictionary of Environmental Technology: } \\
\text { English-German, (Bongaerts \& Newland 1997) }\end{array}$ & $\begin{array}{ll}628.03 & \text { Environmental } \\
\text { Engineering } & \end{array}$ \\
\hline $\begin{array}{l}\text { Routledge Spanish Dictionary of Environmental Technology: } \\
\text { English-Spanish (Gaspar Paricio 1998) }\end{array}$ & $\begin{array}{ll}628.03 & \text { Environmental } \\
\text { Engineering } & \end{array}$ \\
\hline $\begin{array}{l}\text { Gordon T., 1997, Routledge French Dictionary of Environmental } \\
\text { Technology: English-French, London : Routledge. }\end{array}$ & $\begin{array}{ll}628.03 & \text { Environmental } \\
\text { Engineering } & \end{array}$ \\
\hline
\end{tabular}




\begin{tabular}{|c|c|}
\hline $\begin{array}{l}\text { Porteous A., 2000, Dictionary of Environmental Science and } \\
\text { Technology, Chichester: Wiley. }\end{array}$ & $\begin{array}{ll}628.03 & \text { Environmenta } \\
\text { Engineering } & \end{array}$ \\
\hline $\begin{array}{l}\text { Processing Water, Wastewater, Residuals, and Excreta for Health } \\
\text { and Environmental Protection: an Encyclopedic Dictionary (Nicolas } \\
\text { 2008) }\end{array}$ & $\begin{array}{l}628.162 \text { Sanitary Engineering } \\
\text { - Water Supply }\end{array}$ \\
\hline Questions Dictionary of Geography \& Environment (Palmer 2000) & 910.3 Geography and Travel \\
\hline $\begin{array}{l}\text { Illustrated Dictionary and Resource Directory of Environmental } \\
\text { and Occupational Health (Koren 2003) }\end{array}$ & $\begin{array}{l}616.98003 \text { Non-communicable } \\
\text { diseases and environmenta } \\
\text { medicine }\end{array}$ \\
\hline $\begin{array}{l}\text { Dictionary of Environmental and Occupational Medicine (Ohrbach } \\
\text { 2001) }\end{array}$ & $\begin{array}{l}616.98003 \text { Non-communicable } \\
\text { diseases and environmenta } \\
\text { medicine }\end{array}$ \\
\hline Dictionary of Environmental Health (Worthington 2003) & $\begin{array}{l}363.7003 \quad \text { Environmenta } \\
\text { Protection Dictionaries }\end{array}$ \\
\hline $\begin{array}{l}\text { The VNR dictionary of environmental health and safety (Lisella } \\
\text { 1994) }\end{array}$ & $\begin{array}{l}363.7003 \quad \text { Environmenta } \\
\text { Protection Dictionaries }\end{array}$ \\
\hline $\begin{array}{l}\text { Vincoli, J. W., 1999, Lewis dictionary of occupational and } \\
\text { environmental safety and health, Boca Raton, FL: Lewis Publishers. }\end{array}$ & $\begin{array}{l}363.7003 \quad \text { Environmenta } \\
\text { Protection Dictionaries }\end{array}$ \\
\hline $\begin{array}{l}\text { The Environmental Dictionary and Regulatory Cross-reference } \\
\text { (King 1995) }\end{array}$ & 340 Law \\
\hline Dictionary of Environmental Law (Gilpin 2000) & 340 Law \\
\hline Dictionary of Environmental Legal Terms (Lee 1997) & 340 Law \\
\hline Dictionary of Environmental Science for Lawyers (Battersby 1997) & 577 Ecology \\
\hline $\begin{array}{l}\text { Dictionary and Introduction to Global Environmental Governance } \\
\text { (Meganck \& Saunier 2009) }\end{array}$ & $\begin{array}{l}363.7003 \quad \text { Environmenta } \\
\text { Protection Dictionaries }\end{array}$ \\
\hline $\begin{array}{l}\text { Historical Dictionary of North American Environmentalism } \\
\text { (Schwartz \& Wells 1997) }\end{array}$ & $\begin{array}{l}363.7003 \quad \text { Environmenta } \\
\text { Protection Dictionaries }\end{array}$ \\
\hline
\end{tabular}

\section{NOTES}

1. "The beliefs behind an organized social movement of people who share a concern about solving problems of environmental pollution and natural resources" (Park 2007: 155).

2. Having to do with the protection, preservation or regeneration of the environment.

3. For some works, the details provided by the online catalogue are limited.

4. As the number 300 is used to refer to the whole class of social sciences, 300 cannot be used to refer to the sub-category, which is why I have chosen to specify that Sociology and Anthropology are represented by numbers ranging from 301 to 309. 
5. After having obtained an overview of the Dewey categories for each dictionary, we selected a few dictionaries on which to concentrate for this study. Rather than considering dictionaries from each different specialisation, focussing on a selection of dictionaries with key words from the same discipline appeared to be a more appropriate choice in order to compare their Dewey classifications. The dictionaries that were selected have key words from economics, environmental engineering, law and health.

6. The key words identified figure in bold type.

7. The list goes on, but these 28 terms offer a representative sample.

8. Global climatology and weather.

9. The list goes on, but these 28 terms offer a representative sample.

10. As shown in table 4 the category 628 refers to sanitary and municipal engineering.

\section{ABSTRACTS}

The environmental domain seems to be a good example of an emerging specialised field; yet when trying to define what it embraces, one is soon confronted with the problem of the multidisciplinarity which is needed to address its issues. So as to sketch a cartography of this emerging specialised domain, the author looks at what is being done, in terms of classification, by those whose profession it is to do so. All libraries have to establish order in the huge web of knowledge. In this perspective, she considers the classification of environmental dictionaries at The British National Library. After a short presentation of the Dewey classification system, a close examination is made of the different sub-categories in which environmental dictionaries are organised in its catalogue. It provides a telling illustration of how scattered the specialised knowledge needed to understand environmental issues is today. So as to understand the varied classification choices, key words in the titles are analysed as well as the content.

Le domaine environnemental semble un bon exemple d'un domaine spécialisé émergent, mais lorsqu'on essaie de définir ce que ce domaine comprend on est rapidement confronté au problème de la multidisciplinarité nécessaire pour aborder les questions qu'elle soulève. Afin d'ébaucher une cartographie de ce domaine spécialisé émergent, l'auteur observe ce qui est fait en ce qui concerne la classification par ceux dont c'est la profession. Toutes les bibliothèques doivent mettre de l'ordre dans le gigantesque réseau du savoir. Dans cette perspective, elle examine la classification des dictionnaires environnementaux à la British National Library. Après une courte présentation du système de classification Dewey, elle propose un examen détaillé des différentes sous-catégories dans lesquelles les dictionnaires environnementaux sont classés dans le catalogue. Afin de comprendre les choix de classification variés, les mots clés dans le titre sont analysés ainsi que leur contenu.

\section{INDEX}

Mots-clés: domaine environnemental, domaine spécialisé, multidisciplinarité, système de classification Dewey

Keywords: environmental field, Dewey classification system, multidisciplinarity, specialised domain 


\section{AUTHOR}

\section{CAMILLE BIROS}

Camille Biros is a Lecturer at the Medical School Language Department of Joseph Fourier University. She currently teaches English for Medecine, Pharmacy and Biotechnology. She is a member of GREMUTS (Groupe de Recherche Multilingue en Traduction Spécialisée). Her research deals with specialised discourse from the environmental domain. camille.biros@ujf-grenoble.fr 